\title{
Structure of African Populations of Pyricularia oryzae from Rice
}

\author{
Théophile Odjo, ${ }^{1}$ Diariatou Diagne, ${ }^{2}$ Henri Adreit,${ }^{3}$ Joëlle Milazzo, ${ }^{3}$ Harinjaka Raveloson, ${ }^{4}$ \\ Dodelys Andriantsimialona, ${ }^{4,5}$ Abalo Itolou Kassankogno, ${ }^{6}$ Sébastien Ravel, ${ }^{3}$ Yawovi Mawuéna Dieudonné Gumedzoé, ${ }^{7}$ \\ Ibrahima Ouedraogo, ${ }^{6}$ Ousmane Koita, ${ }^{2}$ Drissa Silué, ${ }^{\circ}$ and Didier Tharreau ${ }^{3, \dagger}$ \\ ${ }^{1}$ Faculté des Sciences Agronomiques de l'Université d'Abomey-Calavi, 01 BP526 Cotonou, Bénin \\ ${ }^{2}$ Laboratoire de Biologie Moléculaire Appliquée, Université des Sciences, des Techniques et des Technologies de Bamako, Faculté des \\ Sciences et Techniques, BP E 3206 Bamako, Mali \\ ${ }^{3}$ UMR BGPI, CIRAD, TA A54/K, 34398 Montpellier, France. BGPI, Université de Montpellier, CIRAD, INRA, Montpellier SupAgro, \\ Montpellier, France \\ ${ }_{5}^{4}$ Centre Régional de Recherches Fofifa, 110 BP230 Antsirabe, Madagascar \\ ${ }_{6}^{5}$ South Green Bioinformatics Platform, Bioversity, CIRAD, INRA, IRD, 34398 Montpellier, France \\ ${ }^{6}$ Institut de l'Environnement et Recherches Agricoles, BP 910 Bobo-Dioulasso, Burkina Faso \\ ${ }^{7}$ Ecole Supérieure d'Agronomie de l'Université de Lomé, 01 BP1515 Lomé, Togo \\ ${ }^{8}$ Africa Rice Center, Cotonou, 01 BP2031 Bénin \\ Accepted for publication 22 December 2020.
}

\begin{abstract}
Rice blast, caused by the filamentous ascomycete Pyricularia oryzae, is one of the most devastating diseases of rice. Four genetic clusters were previously identified, and three have a large geographic distribution. Asia is the center of diversity and the origin of most migrations to other continents, and sexual reproduction persisted only in the South China-Laos-North Thailand region, which was identified as the putative center of origin of all $P$. oryzae populations on rice. Despite the importance of rice blast disease, little is known about the diversity and the population structure of the pathogen in Africa (including Madagascar). The present study was intended to describe the structure of African populations of $P$. oryzae and identify the relationship between African and

markers to assess the diversity and the population structure of $P$. oryzae. Four genetic clusters were identified in Africa and Madagascar. All four clusters previously identified are present in Africa. Populations from West Africa, East Africa, and Madagascar are highly differentiated. The geographic structure is consistent with limited dispersion and with some migration events between neighboring countries. The two mating types are present in Africa with a dominance of Mat1.2, but no female-fertile strain was detected, supporting the absence of sexual reproduction on this continent. This study showed an unsuspected high level of genetic diversity of $P$. oryzae in Africa and suggested several independent introductions.
\end{abstract} worldwide genetic clusters. A set of 2,057 strains (937 African and 1,120 Madagascan strains) were genotyped with 12 simple sequence repeat
Keywords: ecology and epidemiology, mycology, population biology
The ascomycete fungus Pyricularia oryzae (syn. Magnaporthe oryzae) is a haploid fungus, responsible for the most damaging disease of rice worldwide: blast. This model species for the study of host-pathogen interactions (Dean et al. 2012) is a major threat to food security (Pennisi 2010). The first written record about rice blast was probably made in China and dates back to 1637 (Ou 1985). Since then, this disease has been reported in all rice producing areas.

The genetic diversity of $P$. oryzae was characterized in many studies via molecular markers, based mainly on repetitive DNA sequences (Hamer et al. 1989), and clonal lineages were described in several countries or continents: India (Kumar et al. 1999), China

\section{${ }^{\dagger}$ Corresponding author: D. Tharreau; tharreau@cirad.fr}

T. Odjo and D. Diagne contributed equally to the work.

Funding: This work was supported by grants from CGIAR (Menergep project [Grisp] and RICE CRP), financial support from the Nick Talbot lab to T. Odjo, a grant from the French Embassy in Mali to D. Diagne, IRD support to the Ousmane Koita group (JEAI COANA), and the support of institutes of the authors (Centre de Coopération Internationale en Recherche Agronomique pour le Développement, INERA, USTTB).

*The $\boldsymbol{e}$-Xtra logo stands for "electronic extra" and indicates that six supplementary tables and one supplementary figure are published online.

The author(s) declare no conflict of interest.

(c) (1) (s) $\odot$ Copyright (C) 2021 The Author(s). This is an open access article distributed under the CC BY-NC-ND 4.0 International license.
(Chen et al. 2006), Thailand (Zeigler 1998), Japan (Don et al. 1999a), Korea (Park et al. 2003, 2008), Philippines (Chen et al. 1995; Zeigler et al. 1995), Vietnam (Don et al. 1999b), Europe (Piotti et al. 2005; Roumen et al. 1997), Iran (Javan-Nikkah et al. 2004), the United States (Correll et al. 2009; Levy et al. 1991; Wang et al. 2017; Xia et al. 1993, 2000), Argentina (Consolo et al. 2008), Colombia (Levy et al. 1993; Zeigler 1998), and Cuba (Fuentes et al. 2003). In West and East Africa, the diversity studies of $P$. oryzae focused mainly on trap analysis in rice resistance screening sites (so-called blast nurseries; Nutsugah et al. 2008; Odjo et al. 2011; Séré et al. 2004; Takan et al. 2012). However, little is known about the diversity and population structure of the pathogen in Africa. Onaga et al. (2015) investigated the population structure, pathogenicity, and mating type distribution of 65 strains of $P$. oryzae from East Africa, eight strains from West Africa, 14 from the Philippines, and one from Japan, using amplification fragment length polymorphism markers and mating type-specific primer sets. From this study, five genetic groups were resolved, and the results showed a clear separation of the Asian strains from the African groups. No evidence of population structure was found among the 65 strains from East Africa (14 strains from Tanzania, 20 from Rwanda, and 31 strains from Uganda), which was interpreted as high gene flow among East Africa populations. The number of West Africa strains was too small to draw any conclusions. Mutiga et al. (2017) also studied the genetic diversity of $P$. oryzae populations from rice and evaluated the virulence spectrum of this pathogen in West Africa (Benin, Burkina Faso, Mali, Ghana, 
Nigeria, and Togo) and East Africa (Kenya, Tanzania, and Uganda). Diversity analysis was based on single-nucleotide polymorphism markers using genotyping-by-sequencing from the 86 isolates. The study identified seven genetic groups and showed a differentiation between West and East African isolates.

By comparing the number of clonal lineages identified in different studies, Zeigler (1998) concluded that the genetic diversity of $P$. oryzae was higher in the area encompassing South, East, and Southeast Asia than in other regions. The most exhaustive studies of the population's structure of $P$. oryzae at the worldwide scale depicted a genetic structure of three or four main clusters distributed widely, with Asian strains scattered in four clusters (Gladieux et al. 2018; Saleh et al. 2014; Tharreau et al. 2009; Thierry et al. 2020; Zhong et al. 2018). These studies concluded that Asia was the center of diversity and the origin of most migrations to other continents. It was also shown that the South China-Laos-North Thailand region is the unique area where sexual reproduction might persist and that it is the putative center of origin of all $P$. oryzae populations on rice (Saleh et al. 2014). In other parts of the world, strains of different genetic clusters can coexist without exchanging genes (Thierry et al. 2020). Unfortunately, African strains were scarcely represented in these studies (Gladieux et al. 2018; Saleh et al. 2014; Tharreau et al. 2009; Thierry et al. 2020; Zhong et al. 2018).

Crop domestication, diversity, and structure are known to influence the emergence and evolution of plant pathogens (Gladieux et al. 2010; Saleh et al. 2014; Stükenbrock and McDonald 2008; Stükenbrock et al. 2011). In Africa, two rice species are cultivated. Oryza sativa was introduced from Asia by the Portuguese as early as the mid-16th century (Portéres 1962). Like Asia, Africa experienced the domestication of a rice species, O. glaberrima. Indeed, native to sub-Saharan Africa, $O$. glaberrima is thought to have been domesticated from the wild ancestor $O$. barthii (formerly known as $O$. brevilugata) by people living in the floodplains at the bend of the Niger River some 2,000 to 3,000 years ago (Portéres 1962, 1976). Population genomics analyses of $20 \mathrm{O}$. glaberrima and $94 O$. barthii accessions demonstrated that $O$. glaberrima was domesticated in a single region along the Niger River (Wang et al. 2014). Today, the species $O$. sativa is dominant in West Africa, whereas $O$. glaberrima and $O$. barthii are rarely found in the region. However, the existence of two potential host species in Africa may have influenced the population structure of the rice blast fungus. There have been no blast population studies conducted on African cultivated or wild species of rice to date.

To investigate the population structure and diversity of $P$. ory$z a e$ in Africa (including Madagascar), we collected 2,057 strains from West Africa, East Africa, and Madagascar, mainly from 2009 to 2018 . They were analyzed with 12 simple sequence repeat (SSR) markers, and the genotypes obtained were compared with the strains of the worldwide sample of Saleh et al. (2014). These SSR markers were previously used successfully to characterize the genetic structure of the blast fungus populations (Saleh et al. 2014). We used the same markers to allow comparison with previous published results. We aimed at answering the following questions: What is the population structure of $P$. oryzae in Africa? Do African strains originate from Asia? Are there specific genetic clusters of $P$. oryzae in Africa? and Is there sexual reproduction of P. oryzae in Africa?

\section{MATERIALS AND METHODS}

Strains collection, isolation, and storage. The collection consisted of strains isolated from cultivated rice, mainly between 2009 and 2018, from farmers' or experimental fields (Supplementary Table S1). Rice diseased samples were collected in farmer fields from four different ecologies-irrigated, rainfed lowland, upland, and flooded upland-in nine countries of West Africa (Benin,
Burkina-Faso, Ghana, Ivory Coast, Mali, Niger, Nigeria, Senegal, and Togo), six countries in East and Central Africa (Burundi, Cameroon, Kenya, Mozambique, Tanzania, and Uganda), and Madagascar. Some samples were collected in field experiments on differential varieties (near isogenic lines) with known resistance genes to blast and commonly used to characterize the virulence spectrum of blast isolates. A total of 2,057 strains-Benin (165), Burkina Faso (210), Ivory Coast (51), Ghana (4), Kenya (5), Mali (105), Niger (14), Nigeria (245), Tanzania (94), Mozambique (1), Togo (34), Senegal (1), Uganda (5), Burundi (2), Cameroon (1), and Madagascar $(1,120)$ - were used to investigate the population structure of $P$. oryzae in Africa. Most strains from countries with small sample sizes (one to five) were included in the analyses because they represent historic reference strains in our collection. To compare our results with the worldwide survey of Saleh et al. (2014) we included in relevant analyses the genotyping data of 804 strains from Asia, Europe, and the Americas. The genotypic data of 354 Madagascan strains from the study of Saleh et al. (2014) were also part of the 1,120 Madagascan genotypic dataset used in this study. Fungal strains were isolated from infected plant material placed in a humid chamber at $25^{\circ} \mathrm{C}$ for 1 to 2 days, and genetically pure fungal strains were obtained by monospore isolation. Fungal strains were grown on a 7-cm-diameter paper disk (Whatman no. 5) placed on autoclaved rice flour medium (20 g of rice flour, $15 \mathrm{~g}$ of agar, $2.5 \mathrm{~g}$ of yeast extract, 500,000 units of penicillin, and 1 liter of water), as previously described (Silué and Nottéghem 1990). After colonization of the paper by the mycelium (i.e., about 7 days in a climatic chamber with $25^{\circ} \mathrm{C}$, fluorescent lighting, 12-h photoperiod), the paper was removed, dried in an oven at $37^{\circ} \mathrm{C}$ for 5 days, cut in pieces for collection in a sterile paper bag, numbered, bagged in a vacuum-sealed plastic bag, and stored at $-20^{\circ} \mathrm{C}$, as described by Valent et al. (1986).

DNA extraction and SSR amplification. DNA extraction was performed according to the procedure described by Adreit et al. (2007). Paper stocks were deposited on rice flour medium maintained in a climatic chamber for 4 to 5 days to obtain actively growing mycelium. This mycelium was used to inoculate $6 \mathrm{ml}$ of 2YEG liquid medium ( $2 \mathrm{~g}$ of yeast extract, $10 \mathrm{~g}$ of glucose, $3 \mathrm{~g}$ of $\mathrm{KNO}_{3}, 2 \mathrm{~g}$ of $\mathrm{KH}_{2} \mathrm{PO}_{4}, 500,000$ units of penicillin, and 1 liter of water). Cultures were maintained 4 days in the dark at $25^{\circ} \mathrm{C}$. The mycelium from this culture was collected for the extraction of genomic DNA according to the Adreit et al. (2007) protocol.

Twelve SSR markers (Supplementary Table S2), previously developed for population genetics studies of $P$. oryzae (Adreit et al. 2007; Kaye et al. 2003; Saleh et al. 2014) were used in this study. These markers were amplified by PCR (QIAGEN Multiplex PCR kit). PCR assays were run with a total volume of $5 \mu \mathrm{l}$, including $2.5 \mu \mathrm{l}$ of Master Mix, $0.5 \mu \mathrm{l}$ of $10 \times$ Mix primers, $0.5 \mu 1$ of $5 \times \mathrm{Q}$ solution, and $1.5 \mu \mathrm{l}$ of genomic DNA $(10 \mathrm{ng} / \mu \mathrm{l})$. The PCR program was performed as follows: predenaturation at $95^{\circ} \mathrm{C}$ for $15 \mathrm{~min}$, denaturation at $94^{\circ} \mathrm{C}$ for $30 \mathrm{~s}$, hybridization at 57 to $63^{\circ} \mathrm{C}$ for $90 \mathrm{~s}$, extension at $72^{\circ} \mathrm{C}$ for $60 \mathrm{~s}$, repeat the first four steps for 40 cycles, and final extension at $72^{\circ} \mathrm{C}$ for $30 \mathrm{~min}$. The products obtained were separated and analyzed on a 16-capillary ABI Prism 3130XL machine (Applied Biosystems, Foster City, $\mathrm{CA}$ ), and the size of the amplicons was assessed by fluorescence measurement. For this analysis, $1.5 \mu \mathrm{l}$ of amplified products (1/70 dilution) was mixed with $15 \mu \mathrm{l}$ of Formamide HiDi and GeneScan-500LIZ size marker (Applied Biosystems). The raw data collected were then analyzed and converted to allele size with GeneMapper 4 software (Applied Biosystems).

Determination of mating type and fertility. To make assumptions about the occurrence of sexual reproduction of $P$. ory$z a e$ in Africa, the mating types of 435 strains and the female fertility of 245 of them were determined. These 435 strains were chosen after preliminary analysis of genotyping data to be representative of the diversity of $P$. oryzae populations in Africa. The mating types 
and female-fertility of 245 African strains were determined by in vitro crosses as described by Nottéghem and Silué (1992). Mating of $P$. oryzae requires strains of opposite mating types, and at least one of the strains must be female-fertile (i.e., able to produce perithecia). Crosses were performed by confronting the tested strain to hermaphroditic strains for which the mating type is known (reference strains). Mat1.1 reference strains used were the Chinese strains CH999 and CH1003, and Mat1.2 reference strains were the Chinese strains CH997 and CH1019 (Saleh et al. 2012a). Tested strains were classified as Mat1.1 when inducing or forming perithecia with a Mat1.2 reference strain (and conversely). Tested strains were classified as female-fertile when forming perithecia with reference strains. The mating types of 190 additional strains were determined by PCR amplification with the primers specific for Mat1.1 (primers A1 and A5) and Mat1.2 (primers B15 and B16; Xu and Hamer 1995). PCR assays were run with a total volume of $19 \mu \mathrm{l}$ (for each mating type of a fungal strain), including $11 \mu \mathrm{l}$ of sterile MiliQ $\mathrm{H}_{2} \mathrm{O}, 2 \mu \mathrm{l}$ of $10 \times$ PCR buffer, $2 \mu \mathrm{l}$ of deoxynucleoside triphosphates (10 mM each), $0.8 \mu \mathrm{l}$ of $\mathrm{MgCl} 2(15 \mathrm{mM}), 1 \mu \mathrm{l}$ of specific primer, $0.2 \mu \mathrm{l}$ of Taq polymerase, and $2 \mu \mathrm{l}$ of DNA solution. The PCR program was predenaturation at $95^{\circ} \mathrm{C}$ for $5 \mathrm{~min}$, denaturation at $95^{\circ} \mathrm{C}$ for $1 \mathrm{~min}$, hybridization at $60^{\circ} \mathrm{C}$ for $2 \mathrm{~min}\left(55^{\circ} \mathrm{C}\right.$ for Mat1.2), amplification at $72^{\circ} \mathrm{C}$ for $2 \mathrm{~min}$, repeat the first four steps for 29 cycles, and elongation at $72^{\circ} \mathrm{C}$ for $5 \mathrm{~min}$. The product of the PCR amplification was then deposited on a $1 \%$ agar gel in TAE buffer and separated electrophoretically for $90 \mathrm{~min}$ at $130 \mathrm{~V}$. Visual scoring was made under UV light after staining for $15 \mathrm{~min}$ in ethidium bromide $(0.5 \mu \mathrm{g} / \mathrm{ml})$. For the strains assessed only by PCR amplification, female fertility was not assessed.

Multilocus genotypes, clustering, and assignment analyses. All 2,862 strains analyzed had no more than three missing loci per strain, and overall, $7 \%$ of the genotypic data were missing. Because $P$. oryzae is haploid, each missing data point corresponds to a missing locus. Polymorphism information content (PIC) was used to evaluate the diversity of SSR markers. PIC value for each SSR was calculated as PIC $=1-\Sigma(P i)^{2}$, where $P i$ stands for the $i$ th allele frequency of one SSR locus (Anderson et al. 1993; Botstein et al. 1980).

To clarify the genetic structure of $P$. oryzae populations in Africa and compare with populations from other continents, we first studied the overall genetic structure. Because $P$. oryzae populations are clonal in most parts of the world (Saleh et al. 2014; Thierry et al. 2020), we first identified and analyzed the distributions of multilocus genotypes (MLGs) present in the African population. Then, we studied their grouping into genetic clusters. Strains were assigned to a particular MLG when they share the same alleles at all loci. This assignment was done with a script developed in house by Sebastien Ravel (https://pypi.org/project/MLG-assign/). This script compares genotypes and deals with missing data. If because of missing data a strain is potentially assigned to two MLGs, the script does not assign the strain to any MLG.

To determine the putative origin of African populations of $P$. oryzae, we compared these populations with populations from other continents. Because four genetic clusters were previously described to have migrated worldwide from Asia (Gladieux et al. 2018; Thierry et al. 2020), we decided that analyzing the population structure at the genetic cluster level was needed. Thus, we assigned MLGs to genetic clusters determined de novo in this study. We used the discriminant analysis of principal components (DAPC; Jombart et al. 2010) that does not require any assumption about the biology of the organism, especially regarding panmixia. The DAPC was conducted in the "adegenet" package of R software (version 3.2.2) (Jombart 2008; Jombart and Ahmed 2011; The R Project for Statistical Computing 2017). The find.clusters function was used to determine the optimal number of genetic clusters $(\mathrm{K})$ based on the Bayesian information criterion.

Indices of genetic diversity in genetic groups. To characterize the diversity, for each genetic group identified after DAPC analysis and for the six geographic regions sampled (East Africa, West Africa, Madagascar, Americas, Asia, and Europe), the mean number of alleles per locus $\mathrm{Na}$, and the unbiased gene diversity

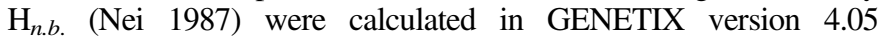
(Belkhir et al. 2004). We calculated the mean number of private alleles $\left(N_{p}\right)$ as the number of alleles that were present only in one genetic group, averaged over all markers.

Genetic differentiation and genetic distances. Pairwise $F_{S T}$ (Weir and Cockerham 1984) was calculated between genetic clusters. It was also calculated between populations from geographic subregions in Africa and from different continents. The null hypothesis $F_{S T}=0$ was tested via exact tests implemented in Genepop version 4 (Raymond and Rousset 1995). The proportion of the shared alleles between genetic clusters was calculated in Populations software version 1.2.32.

Linkage disequilibrium. Pairwise linkage disequilibrium was tested for all 66 pairs of markers and for populations from West Africa, East Africa, and Madagascar. Significance at the 0.05 level was tested by an exact test based on 10,000 permutations implemented in Arlequin version 3.5.1.2 (Excoffier and Lischer 2010).

\section{RESULTS}

Genetic structure. Hereafter, "African population" of P. oryzae refers to strains collected in continental Africa and in Madagascar. All 12 microsatellite markers were polymorphic in the African population of $P$. oryzae. The number of alleles per locus ranged from 3 to 12 and averaged 6.3 over all loci (Supplementary Table $\mathrm{S} 2$ ). PIC per locus loci varied from 0.21 to 0.68 and averaged 0.42 over all loci (Supplementary Table S2).

Among the 2,057 strains genotyped from African populations, 1,222 could be unambiguously assigned to one of the 393 MLGs. Figure 1 shows the distribution of the number of MLGs according to the number of strains they represent in P. oryzae African populations. One-hundred forty-eight MLGs were represented by at least two strains, and 245 MLGs were represented by a unique strain (Fig. 1). The most common MLG was represented by 82 strains. The distribution of the number of strains per MLG followed a Pareto distribution and is typical of clonal organisms (Arnaud-Haond et al. 2007).

To further characterize the genetic structure of African populations of $P$. oryzae and compare it with populations from elsewhere, genotyping data of 804 strains from Asia, Europe, and the Americas from the study by Saleh et al. (2014) were added to African and Madagascan strain samples. In total, the genotypic data of 2,861 strains from West and East Africa (937 strains), Madagascar (1,120 strains), Asia (322 strains), Europe (395 strains), and North and South America (87 strains) were analyzed. In a DAPC (Jombart et al. 2010), the 30 principal components retained explained $>90 \%$ of the observed variance. The Bayesian information criterion value regularly decreased with the number of genetic clusters $(\mathrm{K})$. The curve did not show a marked inflection (Supplementary Fig. S1), and we could not determine an optimal $\mathrm{K}$ value based on this method. Alternatively, we applied the recommendation of the DAPC tutorial (Jombart and Collins 2015) and tried to find the value of $\mathrm{K}$ that provides "better, more efficient summaries of the data than others." DAPC was run for K from 2 to 10. The analysis of DAPC results in graphs (Fig. 2) showing that clustering in more than five groups seemed to create an unnecessary and unreliable level of structure. Hence, four clusters ( $K=4$; numbered from 1 to 4; Fig. 2) seemed to best describe the genetic structure of P. oryzae populations. In continental Africa and Madagascar, 1,917 strains out of 2,057 could be assigned to these clusters (Supplementary Table S3). The 140 remaining strains had admix genotypes and were not assigned to a single cluster.

For African and Madagascan strains, the genetic differentiation between genetic clusters measured by the $F_{S T}$ index (Supplementary Table S4) showed high values for all pairwise comparisons. Each cluster was significantly differentiated from the others. The pairwise 


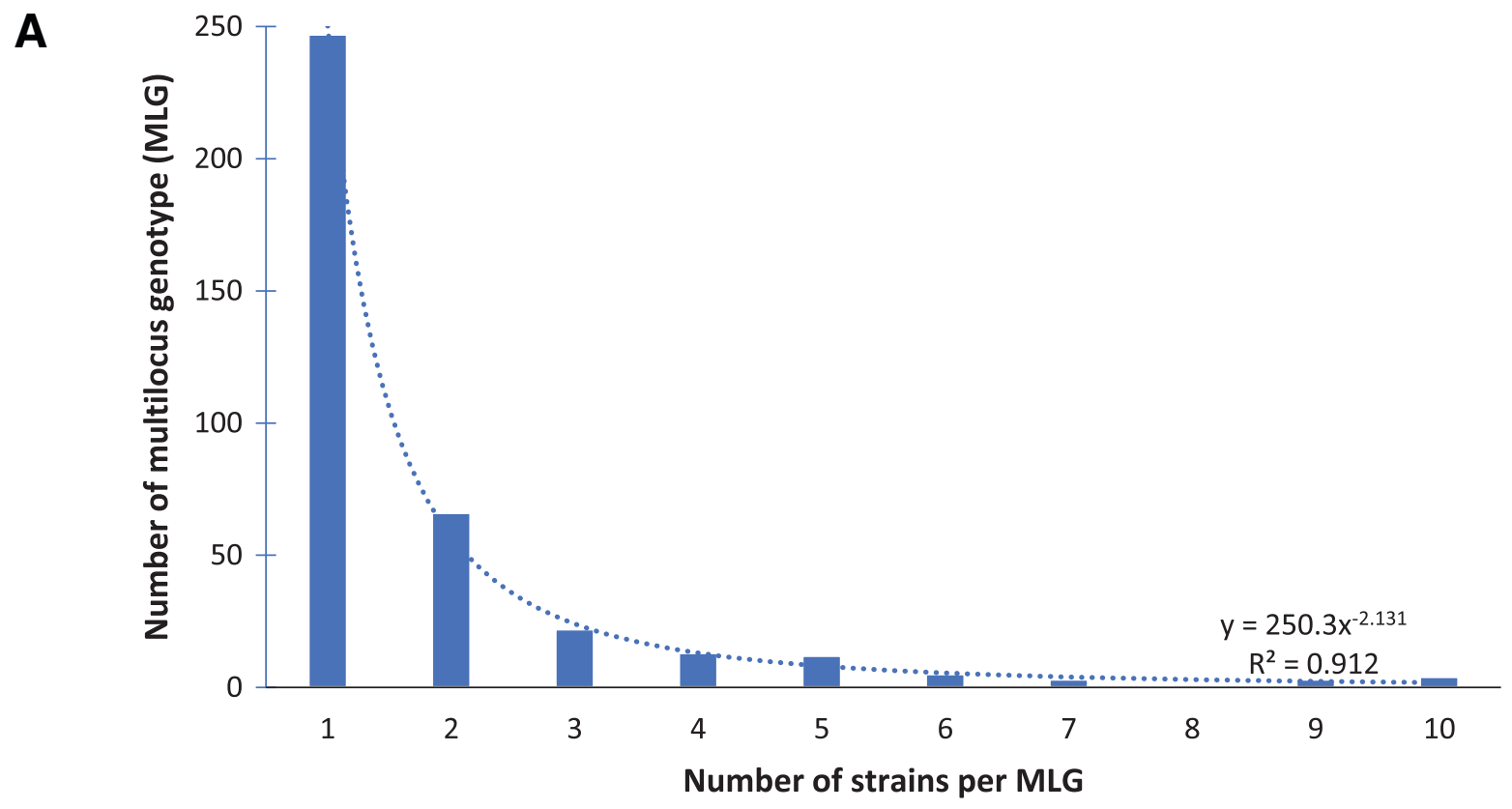

B

\begin{tabular}{lccccccccccccccccccccccccc} 
Number of strains/MLG & 1 & 2 & 3 & 4 & 5 & 6 & 7 & 8 & 9 & 10 & 12 & 13 & 14 & 15 & 16 & 17 & 18 & 20 & 22 & 25 & 29 & 42 & 55 & 61 & 82 \\
\hline Number of MLGs & 245 & 65 & 22 & 13 & 12 & 5 & 3 & 1 & 3 & 4 & 2 & 3 & 1 & 1 & 1 & 1 & 1 & 1 & 2 & 1 & 1 & 2 & 1 & 1 & 1
\end{tabular}

Fig. 1. Distribution of the number of multilocus genotypes (MLGs) according to the number of strains they represent in Pyricularia oryzae African populations. A, Distribution of MLGs encompassing $\geq 10$ strains. B, Distribution of all MLGs.

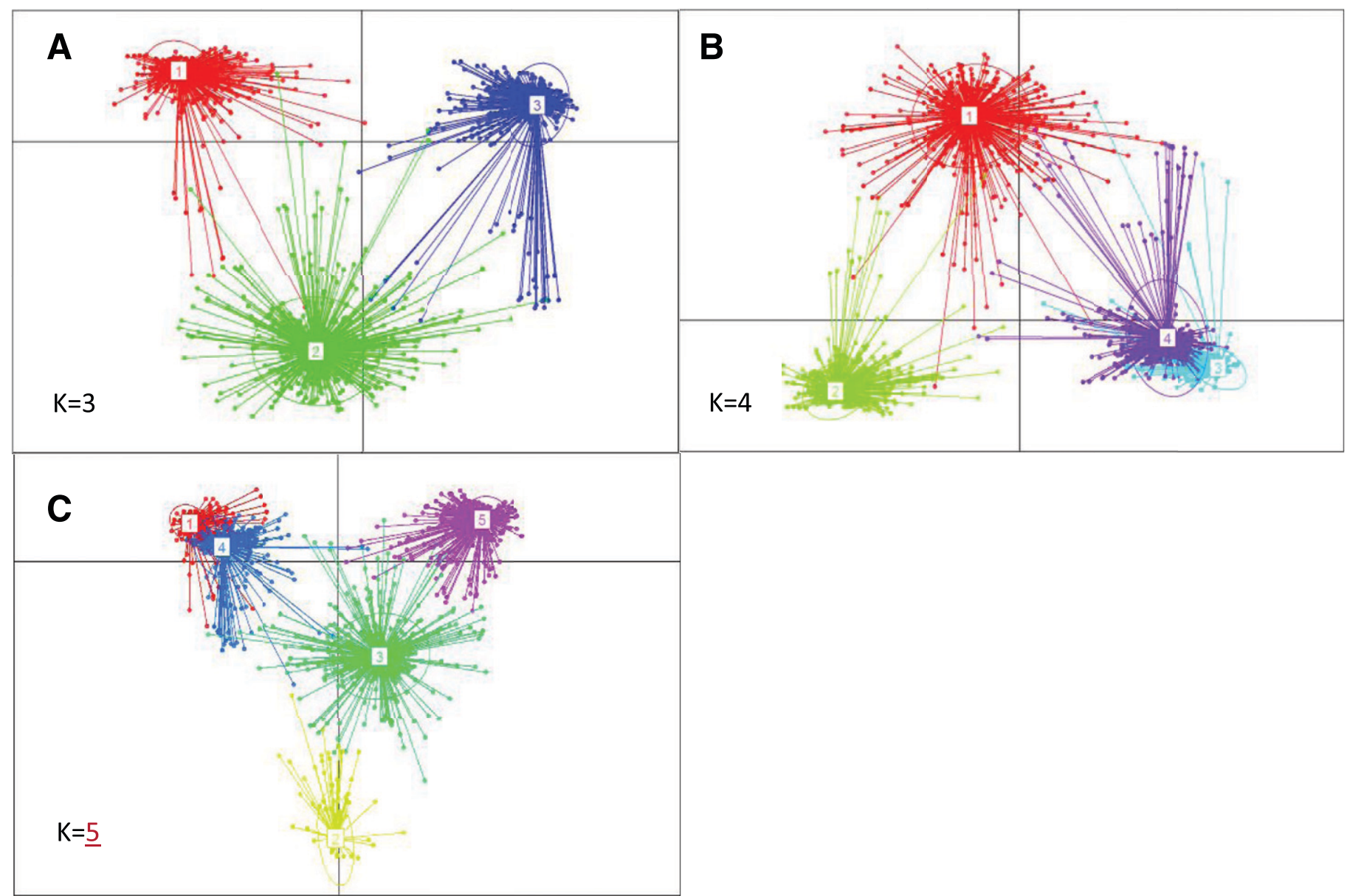

Fig. 2. Clustering of genotypes by discriminant analysis of principal components with number of clusters $(K)$ : $\mathbf{A}, K=3$; $\mathbf{B}, K=4$; and $\mathbf{C}, K=5$. Each color represents a different cluster. 
$F_{S T}$ value varied from 0.37 between genetic clusters (GCs) 1 and 2, to 0.77 , between GC1 and GC3. On average GC2 was the most differentiated cluster $\left(F_{S T}=0.60\right)$ and $\mathrm{GC} 1$ was the least differentiated $\left(F_{S T}=0.41\right)$. The mean number of private alleles $\left(N_{p}\right)$ varied between 0.25 for GC1 and 3.83 for GC4 (Table 1).

We also evaluated the genetic diversity within genetic clusters for African and Madagascan strains. The genetic diversity $\left(H_{n . b .}\right)$ calculated over all individuals within clusters ranged from 0.18 for GC1 to 0.61 for GC4. The mean number of alleles per locus $\left(N_{a}\right)$ varied between 5.1 for GC1 and GC3 to 10 for GC4. So GC1 was the least diverse genetic cluster, whereas GC4 was the most diverse. GC2 and 3 showed intermediate levels of diversity (Table 1).

TABLE 1. Genetic diversity of genetic clusters of Pyricularia oryzae in West Africa, East Africa, and Madagascar

\begin{tabular}{lrrrl}
\hline & & \multicolumn{3}{c}{ Diversity parameters ${ }^{\mathrm{a}}$} \\
\cline { 3 - 5 } Genetic cluster & $N$ & $H_{n . b .}$ & $N_{a}$ & $N_{p}$ \\
\hline 1 & 1,154 & 0.18 & 5.1 & 0.25 \\
2 & 430 & 0.32 & 8.3 & 0.67 \\
3 & 120 & 0.31 & 5.1 & 0.50 \\
4 & 213 & 0.61 & 10 & 3.8 \\
Total & 1,917 & & & \\
\hline
\end{tabular}

${ }^{a} H_{n . b .}$, unbiased gene diversity; $N$, total number of individuals; $N_{a}$, mean number of alleles per locus; $N_{p}$, mean number of private alleles per locus.
Geographic structure in Africa. The differentiation between geographic subregions in Africa was quantified by calculating the differentiation index $F_{S T}$ (Fig. 3). Populations from Madagascar and East Africa were highly differentiated $\left(F_{S T}=0.800\right)$, whereas populations from Madagascar and West Africa on one side and populations from East Africa and West Africa on the other side were moderately differentiated $\left(F_{S T}=0.380\right.$ and 0.384 , respectively).

To further characterize the geographic structure of $P$. oryzae, we studied the distribution of genotypes (MLGs) and of GCs between countries and between subregions (West Africa, East Africa, and Madagascar). Most MLGs were country specific because 139 of 148 MLGs represented by more than one strain were detected only in one country. Ten MLGs were shared between West African countries (Table 2, Supplementary Table S5). Nine of them were shared between two countries and one between three countries. Most of the time, these countries are neighbors (only one exception). In East Africa, no MLGs were shared between countries. Despite the relative proximity between East Africa and Madagascar, no MLGs were shared between the two regions.

In West Africa, all four genetic clusters were observed in five of seven countries (excluding countries with small sample size, i.e., below six strains). Despite shared clusters, each country showed some specificity. GC2 was highly represented $(56.2 \%$ and $42 \%$, respectively) in two countries (Burkina Faso and Nigeria; Table 3, Fig. 4). GC1 dominated in Côte d'Ivoire ( $80.4 \%$ strains), and GC4 dominated in Mali (61\% strains) and Niger (100\%). In Benin GC3

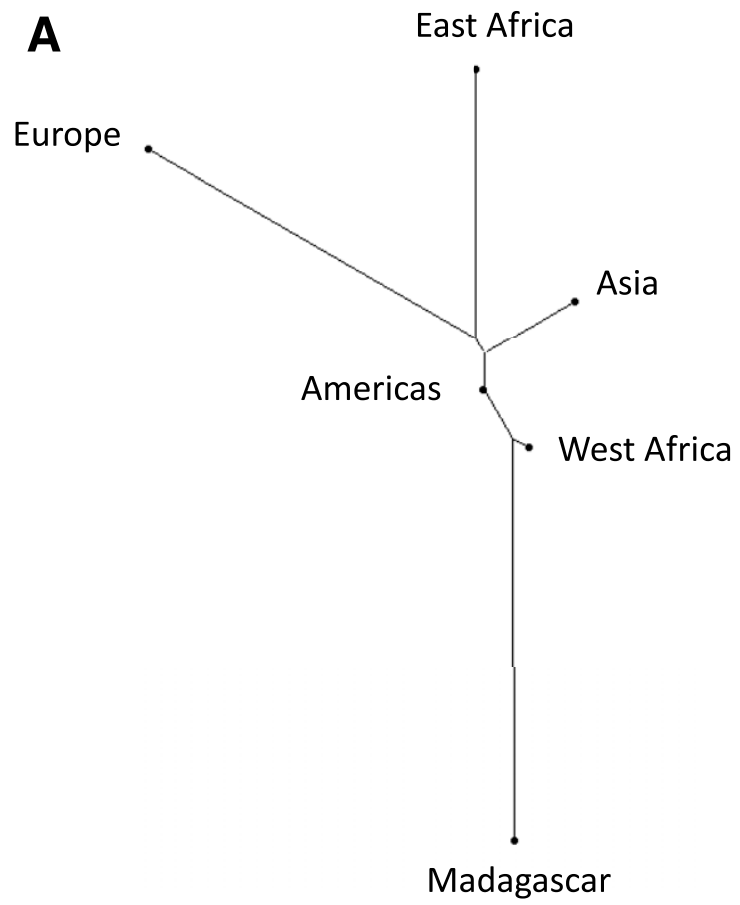

B

\begin{tabular}{lccccc} 
& East Africa & Madagascar & West Africa & Asia & Americas \\
\hline Madagascar & 0.800 & & & & \\
West Africa & 0.384 & 0.381 & & & \\
Asia & 0.344 & 0.651 & 0.190 & & \\
Americas & 0.253 & 0.365 & 0.118 & 0.076 & \\
Europe & 0.587 & 0.768 & 0.501 & 0.461 & 0.369 \\
\hline
\end{tabular}

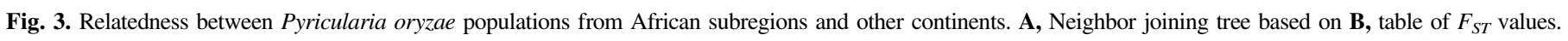

TABLE 2. Geographic distribution of multilocus genotypes (MLGs) shared between countries

\begin{tabular}{|c|c|c|c|c|c|c|c|c|}
\hline MLGs & Genetic clusters & Benin & Burkina Faso & Ghana & Côte d'Ivoire & Mali & Nigeria & Togo \\
\hline 118 & 2 & & 1 & & 2 & & & \\
\hline 119 & 1 & & 5 & & 4 & & & \\
\hline 124 & 2 & 6 & 2 & & & & 1 & \\
\hline 198 & 2 & 3 & 2 & & & & & \\
\hline 200 & 2 & 11 & 2 & & & & & \\
\hline 238 & 2 & & & 1 & & & 54 & \\
\hline 243 & 2 & & & & & 3 & 3 & \\
\hline
\end{tabular}


(45.4\% strains) and GC2 (43\% strains) codominated. In East Africa, all genetic clusters were detected, but limited sample size per country allowed us to describe only the population structure in Tanzania. In this country, only two GCs were detected: GC3 (24.5\% of the strains) and GC4 (75.5\%). In Madagascar, all four GCs were detected, and GC1 was the most represented ( $92 \%$ strains).

Overall, the three subregions showed very different distribution of clusters (Fig. 4, Table 3). GC2, GC4, and GC1 were dominant in West Africa, East Africa, and Madagascar, respectively.
Relationship between African strains and worldwide samples of $\boldsymbol{P}$. oryzae. To make hypotheses about the origin of African populations of $P$. oryzae, we measured the differentiation between populations from geographic subregions in Africa and populations from other continents (Fig. 3). In all pairwise comparisons with other continents, the population from West Africa was the least differentiated and the population from Madagascar was the most differentiated. Populations from West Africa, East Africa, and Madagascar were highly differentiated from the

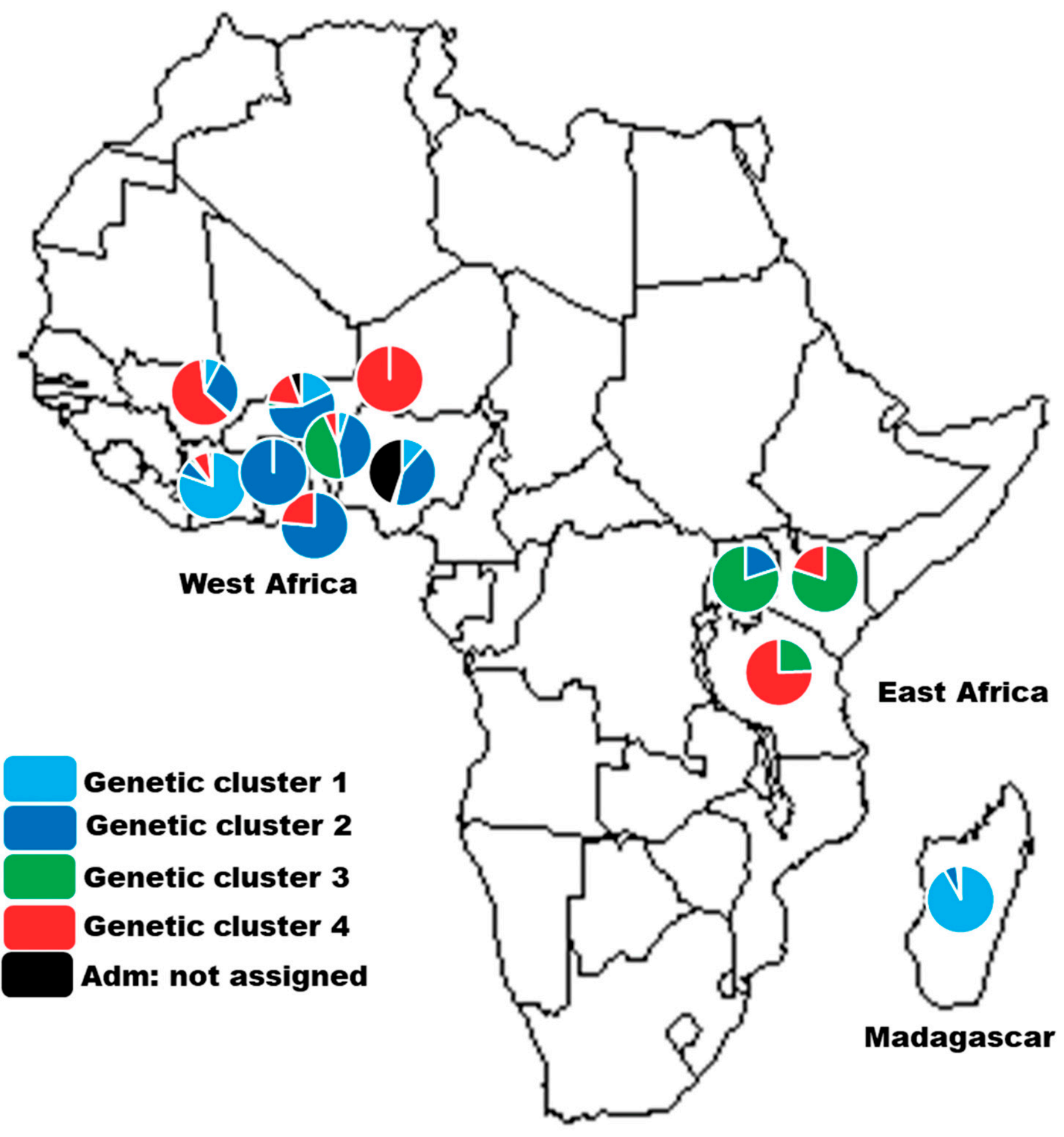

Africa

Fig. 4. Geographic distribution of genetic clusters of Pyricularia oryzae. Discriminant analysis of principal components method was used to classify 937 strains from West and East Africa and 1,120 strains from Madagascar. Adm, admix strains (unassigned to a single genetic cluster), shown in black. 
European population $\left(F_{S T}\right.$ values of $0.501,0.587$, and 0.768 , respectively). The American population showed the lowest differentiation with African populations $\left(F_{S T}\right.$ values of $0.118,0.253$, and 0. 365, respectively, for populations from West Africa, East Africa, and Madagascar). Compared with the American population, the Asian population was slightly more differentiated from the West and East African populations and much more differentiated from the population from Madagascar $\left(F_{S T}\right.$ values of 0.190 , 0.344 , and 0.651 , respectively).

We also compared the genetic clusters found in Africa in this study to those identified on a worldwide sample by Saleh et al.

TABLE 3. Geographic structure of Pyricularia oryzae: number of strains per genetic cluster and country

\begin{tabular}{|c|c|c|c|c|c|c|}
\hline \multirow[b]{2}{*}{ Countries } & \multicolumn{5}{|c|}{ Genetic cluster } & \multirow[b]{2}{*}{ Total } \\
\hline & 1 & 2 & 3 & 4 & $\operatorname{Adm}^{\mathrm{a}}$ & \\
\hline West Africa & & & & & & 829 \\
\hline Nigeria & 28 & 103 & 3 & 1 & 110 & 245 \\
\hline Burkina Faso & 38 & 118 & 5 & 37 & 12 & 210 \\
\hline Benin & 8 & 71 & 75 & 10 & 1 & 165 \\
\hline Mali & 8 & 30 & 1 & 64 & 2 & 105 \\
\hline Côte d'Ivoire & 41 & 4 & 1 & 4 & 1 & 51 \\
\hline Togo & & 26 & & 8 & & 34 \\
\hline Niger & & & & 14 & & 14 \\
\hline Ghana & & 4 & & & & 4 \\
\hline Senegal & & & & & 1 & 1 \\
\hline East and Central & & & & & & 108 \\
\hline Tanzania & & & 23 & 71 & & 94 \\
\hline Kenya & & & 4 & 1 & & 5 \\
\hline Uganda & & 1 & 4 & & & 5 \\
\hline Burundi & 1 & & & 1 & & 2 \\
\hline Mozambique & & 1 & & & & 1 \\
\hline Cameroon & 1 & & & & & 1 \\
\hline Madagascar & 1,029 & 72 & 4 & 2 & 13 & 1,120 \\
\hline Total & 1,154 & 430 & 120 & 213 & 140 & 2,057 \\
\hline
\end{tabular}

${ }^{a}$ Adm, admix strains, unassigned to a single genetic cluster by discriminant analysis of principal components.
(2014) (Table 4). Saleh et al. identified three worldwide genetic clusters (A, B, and C) and four Asian genetic clusters (1 to 4). In our study, 208 of 210 strains previously assigned to worldwide cluster A were assigned to GC4. Asian strains assigned to GC4 in our study were clustered mainly in Asian clusters 1 and $4(39.9 \%$ and $43.3 \%$ of strains, respectively). Most (492 out of 499) of the strains assigned by Saleh et al. to cluster B were assigned to GC3. All 63 Asian strains assigned to GC3 were assigned to Asian cluster 2 by Saleh et al. (2014). Most the strains (327 out of 449) assigned by Saleh et al. (2014) to cluster C were assigned to GC1; 108 were assigned to GC2 (24.1\%), and 14 could not be assigned (3.1\%). Most Asian strains (72 out of 78) assigned to GC2 were assigned to Asian cluster 3 (the remaining strains were not assigned to a unique GC in our study). Altogether, these results show that GC4, GC3, and GC1 identified in this study correspond respectively to clusters A, B, and C of Saleh et al. GC2 also corresponds to cluster C. GC2 and 3 correspond to Asian clusters 3 and 2, respectively, and GC4 gathers strains from Asian clusters 1 and 4.

These results show that the genetic clusters to which African strains belong are also found in other continents. In particular, all genetic clusters identified in Asia by Saleh et al. (2014) are detected in Africa.

MLGs shared between different continents were searched for. We identified no MLGs shared between African and Madagascan strains and other continents. The single shared MLG identified by Saleh et al. (2014) between one strain of Madagascar and one strain of Indonesia was not found because this Indonesian strain was missing in the current dataset. Thus, this strain was excluded from our analyses because of uncertainty about the host of origin, although the identity of genotypes was confirmed by reexamination of the data.

The genotypic diversity in West Africa and Madagascar (Shannon and genotypic diversity indexes in Supplementary Table S3) was higher than in the Americas and Europe. It was lower than in Asia, which is considered the center of diversity (and includes the putative center of origin) of the blast fungus. The population from East Africa was the least diverse.

TABLE 4. Distribution of genetic clusters defined by Saleh et al. (2014) and genetic clusters identified in this study ${ }^{\mathrm{a}}$

\begin{tabular}{|c|c|c|c|c|c|c|c|}
\hline \multicolumn{2}{|c|}{ Genetic group (Saleh et al. 2014) } & \multicolumn{4}{|c|}{ Genetic cluster (this study) } & $\mathrm{Adm}^{\mathrm{b}}$ & Total \\
\hline \multirow[t]{4}{*}{ A } & 1 & & & 2 & 83 & & 85 \\
\hline & 3 & & & & 2 & & 2 \\
\hline & 4 & & & & 90 & & 90 \\
\hline & $\mathrm{NA}^{\mathrm{c}}$ & & & & 29 & & 29 \\
\hline B & 2 & & & 63 & & & 63 \\
\hline & NA & 327 & 36 & & & 8 & 371 \\
\hline \multicolumn{2}{|c|}{ Total world (Saleh et al. 2014) } & 327 & 108 & 494 & 215 & 14 & 1,158 \\
\hline \multicolumn{2}{|c|}{ Africa and Madagascar (this study) } & 1,154 & 430 & 120 & 213 & 140 & 2,057 \\
\hline
\end{tabular}

a A/B/C and 1 to 4 correspond to groups defined by Saleh et al. (2014) for worldwide and Asian samples, respectively.

Adm: admix strains (strains unassigned to a single genetic cluster by DAPC).

${ }^{\mathrm{c}} \mathrm{NA}$, non-Asian strains.

TABLE 5. Distribution of the mating type of 435 selected strains and of the number of strains analyzed for female fertility in the different genetic clusters found in Africa and Madagascar

\begin{tabular}{lrrrrr}
\hline & \multicolumn{3}{c}{ Mating type } & & \\
\cline { 2 - 5 } Genetic cluster & 1.1 & 1.2 & Total & $1: 1$ ratio $\chi^{2}(P)$ & Strains tested for female fertility $(n)^{\mathrm{a}}$ \\
\hline 1 & 1 & 300 & 301 & $297(<0.001)$ & 141 \\
2 & 4 & 72 & 76 & $60.8(<0.001)$ & 54 \\
3 & 17 & 2 & 19 & $11.8(0.001)$ & 18 \\
4 & 20 & 1 & 21 & $17.2(0.001)$ & 21 \\
Adm $^{\mathrm{c}}$ & 0 & 18 & 18 & $18.0(<0.001)$ & 11 \\
Total & 42 & 393 & 435 & $283(<0.001)$ & 213 \\
\hline
\end{tabular}

${ }^{\text {a }}$ Strains were tested in vitro for their female fertility. All tested strains were female-sterile.

${ }^{\mathrm{b}} N$, total number of strains per genetic cluster.

${ }^{c}$ Adm, admix strains unassigned to a single genetic cluster. 
Mating type, fertility of strains, and linkage disequilibrium. The mating type results showed contrasted distributions between West Africa, East Africa, and Madagascar, with Mat1.1/Mat1.2 ratios of 20/72, 20/1, and 1/320, respectively (Supplementary Table S6). These ratios were significantly different from $1: 1\left(\chi^{2}=29.4\right.$, 17.2, and 317.0 respectively; $P<0.001$ for all three tests). Both mating types were found in all GCs (Table 5), but one mating type was largely dominant for each GC: Mat1.1 for GC3 and GC4 (89.5 and $95.2 \%$ of strains, respectively) and Mat1.2 for GC1 and GC2 (99.7 and $94.7 \%$, respectively). All these frequencies were significantly different from $50 \%\left(\chi^{2}=297,60.8,11.8,17.2 ; P \leq 0.001\right.$ for all four tests). None of the 245 strains tested produced perithecia in crossing with reference strains. Thus, no female-fertile strain was identified in this representative sample.

Linkage disequilibrium analysis demonstrated a general trend toward nonrandom association of alleles at different loci for the three geographic populations in Africa. Significant (5\% level) pairwise linkage disequilibrium was detected for 86,95 , and $100 \%$ of the 66 pairs of loci for the populations from West Africa, Madagascar, and East Africa, respectively.

\section{DISCUSSION}

The presence of repeated MLGs, the distribution of strains per MLG, and the nonrandom association of alleles at different loci indicated a clonal structure of the African populations (including Madagascar). Clonal reproduction of $P$. oryzae rice populations is the rule (Saleh et al. 2012a). We here confirmed that both mating types are present in Africa (Nottéghem and Silué 1992; Onaga et al. 2015; Takan et al. 2012) and sometimes in the same country. But the coexistence of strains of both mating types is not sufficient for sexual reproduction to take place. The presence of female-fertile strains is also required (Saleh et al. 2012a,b; Saleh et al. 2014). We did not find any female-fertile strains in Africa. Mating types also deviated significantly from the 1:1 ratio expected for random mating. These result are consistent with the clonal population structure observed and also supports the hypothesis that sexual reproduction is absent in Africa. As shown on a broader scale (Thierry et al. 2020), P. oryzae genetic clusters on rice coexist and have no or very limited gene exchanges out of Asia.

Genetic differentiation between East and West African populations of the rice blast fungus was previously observed by Mutiga et al. (2017) on a limited number of samples. With a larger sample and in a broader geographic area, we revealed that differences between populations from the subcontinental regions of West Africa, East Africa, and Madagascar were marked: There were moderate to high differentiation index values, no MLGs were shared between them, and frequencies of genetic clusters were different between these subregions. Although each country showed specificity, MLGs were shared between neighboring countries in West Africa. This pattern is consistent with a combination of frequent short-distance and rare events of long-distance migrations due to natural dispersion of $P$. oryzae spores and transportation of infected seeds, respectively (Tharreau et al. 2009), with exchanges of infected seeds within a subcontinental region probably being more frequent than between subcontinental regions.

We showed the presence in Africa of the three worldwide clusters and the four Asian clusters previously described (Saleh et al. 2014). To date, Asia is the only continent in which the three worldwide clusters were represented within a given local geographic area. In addition to belonging to all genetic clusters, we identified African populations (genetic cluster 4) related to the Asian clusters 1 and 4, which encompass the most genetically diverse populations (Saleh et al. 2014). This places Africa in second position after Asia in terms of genetic diversity of $P$. oryzae at the continental level. High genotypic diversity could be explained by two mechanisms. Sexual reproduction generates genotypic diversity by recombination. But, based on our results and similarly to other non-Asian populations, sexual reproduction seems unlikely in African $P$. oryzae populations. Genotypic diversity may also result from multiple introductions. This hypothesis is supported by the fact that all genetic clusters found in Africa are also found in Asia. According to the literature, the Asian rice $O$. sativa was introduced to East Africa (by the 10th century $\mathrm{CE}$ ) by Polynesians using the southern Indian Ocean route from Indonesia to Madagascar and the East Coast of Africa (Carpenter 1978; Crowther et al. 2016). It was subsequently introduced to West Africa by the Portuguese in about $1,500 \mathrm{CE}$ via the Atlantic Ocean (Portéres 1950). Introductions of new varieties for the local development of new rice cropping systems and of accessions for breeding purposes have also taken place during the last century, with limited attention to phytosanitary quality of seeds. The high genetic diversity of $P$. oryzae observed in Africa is likely to have resulted from multiple introductions of infected rice seeds.

In summary, this work sheds new light on the genetic structure of $P$. oryzae strains in Africa. Unexpectedly, the genetic diversity of the fungus in Africa is high, placing the continent in second position after Asia. In addition, clusters identified in Africa were shared with other continents, and no genetic clusters specific to Africa was detected. Such diversity increases the risk of emergence of new pathotypes in Africa. Therefore, it is urgent to monitor the evolution of the pathogen populations in this area and to propose new and durable strategies for the deployment of resistance genes, exploiting knowledge of the genetic structure of the pathogen.

\section{ACKNOWLEDGMENTS}

We thank Christophe Tertois and Youssouf Diarra for their contribution. Genotyping data used in this work were produced through the GenSeq technical facilities of the Institut des Sciences de l'Evolution de Montpellier with the support of LabEx CeMEB, an ANR "Investissements d'Avenir" program (ANR-10-LABX-04-01). We also thank the numerous colleagues who collected samples or provided strains.

\section{LITERATURE CITED}

Adreit, H., Kadrawi, S., Andriantsimialona, D., Utami, D. W., Nottéghem, J. L., Lebrun, M. H., and Tharreau, D. 2007. Microsatellite markers for population studies of the rice blast fungus, Magnaporthe grisea. Mol. Ecol. Notes 7:667-670

Anderson, J. A., Churchill, G. A., Autrique, J. E., Tanksley, S. D., and Sorrells, M. E. 1993. Optimizing parental selection for genetic linkage maps. Genome 36:181-186.

Arnaud-Haond, S., Duarte, C. M., Alberto, F., and Serrao, E. A. 2007. Standardizing methods to address clonality in population studies. Mol. Ecol. 16: 5115-5139.

Belkhir, K., Borsa, P., Chikhi, L., Raufaste, N., and Bonhomme, F. 2004. GENETIX 4.05, Logiciel sous Windows TM pour la Génétique des Populations. Laboratoire Génome, Populations, Interactions, CNRS UMR 5171, Université de Montpellier II, Montpellier, France.

Botstein, D., White, R. L., Skolnick, M., and Davis, R. W. 1980. Construction of a genetic linkage map in man using restriction fragment length polymorphisms. Am. J. Hum. Genet. 32:314-331.

Carpenter, A. J. 1978. Rice history. Pages 3-10 in: Rice in Africa. I. W. Buddenhagen, and G. J. Persley, eds. Academic Press, London.

Chen, D. H., Zeigler, R. S., Leung, H., and Nelson, R. J. 1995. Population structure of Pyricularia grisea at two screening sites in the Philippines. Phytopathology 85:1011-1020.

Chen, Q. H., Wang, Y. C., and Zheng, X. B. 2006. Genetic diversity of Magnaporthe grisea in China as revealed by DNA fingerprint haplotypes and pathotypes. J. Phytopathol. 154:361-369.

Consolo, V. F., Cordo, C. A., and Salerno, G. L. 2008. DNA fingerprint and pathotype diversity of Pyricularia oryzae populations from Argentina. Australas. Plant Pathol. 37:357-364.

Correll, J. C., Boza, E. J., Seyran, E., Cartwright, R. D., Jia, Y., and Lee, F. N. 2009. Examination of the rice blast pathogen population diversity in Arkansas, USA: stable or unstable? Pages 217-228 in: Advances in Genetics, Genomics and Control of Rice Blast Disease. G. L. Wang and B. Valent, eds. Springer, Amsterdam, the Netherlands. 
Crowther, A., Lucas, L., Helm, R., Horton, M., Shipton, C., Henry, T., Wright, H. T., Walshaw, S., Pawlowicz, M., Radimilahy, C., Douka, K., Picornell-Gelabert, L., Fuller, D. Q., and Boivin, N. L. 2016. Ancient crops provide first archaeological signature of the westward Austronesian expansion. Proc. Natl. Acad. Sci. USA 113:6635-6640.

Dean, R., Van Kan, J. A., Pretorius, Z. A., Hammond-Kosack, K. E., Di Pietro, A., Spanu, P. D., Rudd, J. J., Dickman, M., Kahmann, R., Ellis, J., and Foster, G. D. 2012. The top 10 fungal pathogens in molecular plant pathology. Mol. Plant Pathol. 13:414-430.

Don, L. D., Kusaba, M., Urashima, A. S., Tosa, Y., Nakayashiki, H., and Mayama, S. 1999a. Population structure of the rice blast fungus in Japan examined by DNA fingerprinting. Ann. Phytopathol. Soc. Jpn. 65:15-24.

Don, L. D., Tosa, Y., Nakayashiki, H., and Mayama, S. 1999b. Population structure of the rice blast fungus in Vietnam. Ann. Phytopathol. Soc. Jpn. 65:475-479.

Excoffier, L., and Lischer, H. E. L. 2010. Arlequin suite ver 3.5: A new series of programs to perform population genetics analyses under Linux and Windows. Mol. Ecol. Resour. 10:564-567.

Fuentes, J. L., Correa-Victoria, F. J., Escobar, F., Mora, L., Duque, M. C., Deus, J. E., and Cornide, M. T. 2003. Genetic diversity analysis of the rice blast pathogen population at two locations in Cuba. Biotecnol. Apl. 20:14-19.

Gladieux, P., Ravel, S., Rieux, A., Cros-Arteil, S., Adreit, H., Milazzo, J., Thierry, M., Fournier, E., Terauchi, R., and Tharreau, D. 2018. Coexistence of multiple endemic and pandemic lineages of the rice blast pathogen. MBio 9:e01806-17.

Gladieux, P., Zhang, X. G., Róldan-Ruiz, I., Caffier, V., Leroy, T., Devaux, M., Van Glabeke, S., Coart, E., and Le Cam, B. 2010. Evolution of the population structure of Venturia inaequalis, the apple scab fungus, associated with the domestication of its host. Mol. Ecol. 19:658-674.

Hamer, J. E., Farrall, L., Orbach, M. J., Valent, B., and Chumley, F. G. 1989. Host species-specific conservation of a family of repeated DNA sequences in the genome of a fungal plant pathogen. Proc. Natl. Acad. Sci. USA 86:9981-9985.

Javan-Nikkah, M., McDonald, B. A., Banke, S., and Hedjaroude, G. A. 2004. Genetic structure of Iranian Pyricularia grisea populations based on re-PCR fingerprinting. Eur. J. Phytopathol. 110:909-919.

Jombart, T. 2008. adegenet: A R package for the multivariate analysis of genetic markers. Bioinformatics 24:1403-1405.

Jombart, T., and Ahmed, I. 2011. adegenet 1.3-1: New tools for the analysis of genome-wide SNP data. Bioinformatics 27:3070-3071.

Jombart, T., and Collins, C. 2015. A tutorial for discriminant analysis of principal components (DAPC) using adegenet 2.0.0. https://adegenet.r-forge. r-project.org/files/tutorial-dapc.pdf

Jombart, T., Devillard, S., and Balloux, F. 2010. Discriminant analysis of principal components: a new method for the analysis of genetically structured populations. BMC Genet. 11:94.

Kaye, C., Milazzo, J., Rozenfeld, S., Lebrun, M. H., and Tharreau, D. 2003. The development of simple sequence repeat markers for Magnaporthe grisea and their integration into an established genetic linkage map. Fungal Genet. Biol. 40:207-214.

Kumar, J., Nelson, R. J., and Zeigler, R. S. 1999. Population structure and dynamics of Magnaporthe grisea in the Indian Himalayas. Genetics 152:971-984.

Levy, M., Correa, F. J., Zeigler, R. S., Xu, S., and Hamer, J. E. 1993. Genetic diversity of the rice blast fungus in a disease nursery in Colombia. Phytopathology 83:1427-1433.

Levy, M., Romao, J., Marchetti, M. A., and Hamer, J. E. 1991. DNA fingerprinting with a dispersed repeated sequence resolves pathotype diversity in the rice blast fungus. Plant Cell 3:95-102.

Mutiga, S. K., Rotich, F., Ganeshan, V. D., Mwongera, D. T., Mgonja, E. M., Were, V. M., Harvey, J. W., Zhou, B., Wasilwa, B., Feng, C., Ouédraogo, I., Wang, G. L., Mitchell, T. K., Talbot, N. J., and Correll, J. C. 2017. Assessment of the virulence spectrum and its association with genetic diversity in Magnaporthe oryzae populations from Sub-Saharan Africa. Phytopathology 107:852-863.

Nei, M. 1987. Page 512 in: Molecular Evolutionary Genetics. Columbia University Press, New York.

Nottéghem, J. L., and Silué, D. 1992. Distribution of the mating type alleles in Magnaporthe grisea populations pathogenic on rice. Phytopathology $82: 421-424$

Nutsugah, S. K., Twumasi, T. K., Chipili, J., Séré, Y., and Sreenivasaprasad, S. 2008. Diversity of the rice blast pathogen populations in Ghana and strategies for resistance management. Plant Pathol. J. 7:109-113.

Odjo, T., Ahohuendo, B. C., Amos, O., Akator, K., and Séré, Y. 2011. Analysis of Magnaporthe oryzae population structure in Benin. Afr. J. Agric. Res. 6:6183-6188.

Onaga, G., Wydra, K., Koopmann, B., Séré, Y., and von Tiedemann, A. 2015. Population structure, pathogenicity, and mating type distribution of Magnaporthe oryzae isolates from East Africa. Phytopathology 105:1137-1145.
Ou, S. H. 1985. Rice Diseases. Vol. 2. Commonwealth Mycological Institute, Kew, UK.

Park, S. Y., Milgroom, M. G., Han, S. S., Kang, S., and Lee, Y. H. 2003. Diversity of pathotypes and DNA fingerprint haplotypes in populations of Magnaporthe grisea in Korea over two decades. Phytopathology 93:13781385.

Park, S. Y., Milgroom, M. G., Han, S. S., Kang, S., and Lee, Y. H. 2008. Genetic differentiation of Magnaporthe oryzae populations from scouting plots and commercial rice fields in Korea. Phytopathology 98:436-442.

Pennisi, E. 2010. Armed and dangerous. Science 327:804-805.

Piotti, E., Rigano, M. M., Rodino, D., Rodolfi, M., Castiglione, S., Picco, A. M., and Sala, F. 2005. Genetic structure of Pyricularia grisea (Cooke) Sacc. isolates from Italian paddy fields. J. Phytopathol. 153:80-86.

Portéres, R. 1950. Vieilles Agricultures de l'Afrique Intertropicale [in French]. Agron. Trop. 5:489-507.

Portéres, R. 1962. Berceaux Agricoles Primaires sur le Continent Africain [in French]. J. Afr. Hist. 3:195-210.

Portéres, R. 1976. African cereals: eleusine, fonio, black fonio, tejf, brachiaria, paspalum, pennisetum, and African rice. Pages 409-452 in: The Origins of African Plant Domestication. J. R. Harlan, J. M. J. de Wet, and A. B. L. Stemler, eds. De Gruyter Mouton, The Hague, The Netherlands.

The R Project for Statistical Computing. 2017. R: A language and environment for statistical computing. R Foundation for Statistical Computing. Vienna, Austria. https://www.R-project.org/

Raymond, M., and Rousset, F. 1995. Genepop (Version-1.2): populationgenetics software for exact tests and ecumenicism. J. Hered. 86:248-249.

Roumen, E., Levy, M., and Nottéghem, J. L. 1997. Characterisation of the European pathogen population of Magnaporthe grisea by DNA fingerprinting and pathotype analysis. Eur. J. Plant Pathol. 103:363-371.

Saleh, D., Milazzo, J., Adreit, H., Fournier, E., and Tharreau, D. 2014. South-East Asia is the center of origin, diversity and dispersion of the rice blast fungus, Magnaporthe oryzae. New Phytol. 201:1440-1456.

Saleh, D., Milazzo, J., Adreit, H., Tharreau, D., and Fournier, E. 2012a. Asexual reproduction induces a rapid and permanent loss of sexual reproduction capacity in the rice fungal pathogen Magnaporthe oryzae: results of in vitro experimental evolution assays. BMC Evol. Biol. 12:42.

Saleh, D., Xu, P., Shen, Y., Li, C. Y., Adreit, H., Milazzo, J., Ravigné, V., Bazin, E., Nottéghem, J. L., Fournier, E., and Tharreau, D. 2012b. Sex at the origin: An Asian population of the rice blast fungus Magnaporthe oryzae reproduces sexually. Mol. Ecol. 21:1330-1344.

Séré, Y., Sy, A. A., Akator, S. K., Onasanya, A., and Zai, K. 2004. Screening strategy for durable resistance to rice blast disease at WARDA. Rice blast in West Africa: Characterization of pathogen diversity, key screening sites and host resistance. WARDA Proc. Ser. 3:4-6.

Silué, D., and Nottéghem, J. L. 1990. Production of perithecia of Magnaporthe grisea on rice plants. Mycol. Res. 94:1151-1152.

Stükenbrock, E. H., Bataillon, T., Dutheil, J. Y., Hansen, T. T., Li, R., Zala, M., McDonald, B. A., Wang, J., and Schierup, M. H. 2011. The making of a new pathogen: Insights from comparative population genomics of the domesticated wheat pathogen Mycosphaerella graminicola and its wild sister species. Genome Res. 21:2157-2166.

Stükenbrock, E. H., and McDonald, B. 2008. The origins of plant pathogens in agro-ecosystems. Annu. Rev. Phytopathol. 46:75-100.

Takan, J. P., Chipili, J., Muthumeenakshi, S., Talbot, N. J., Manyasa, E. O., Bandyopadhyay, R., Sere, Y., Nutsugah, S. K., Talhinhas, P., Hossain, M., Brown, A. E., and Sreenivasaprasad, S. 2012. Magnaporthe oryzae populations adapted to finger millet and rice exhibit distinctive patterns of genetic diversity, sexuality and host interaction. Mol. Biotechnol. 50:145158.

Tharreau, D., Fudal, I., Andriantsimialona, D., Santoso, Utami, D., Fournier, E., Lebrun, M. H., and Nottéghem, J. L. 2009. World population structure and migration of the rice blast fungus, Magnaporthe oryzae. Pages 209215 in: Advances in Genetics, Genomics and Control of Rice Blast Disease. G. L. Wang and B. Valent, eds. Springer, The Netherlands.

Thierry, M., Milazzo, J., Adreit, H., Ravel, S., Borron, S., Sella, V., Ioos, R., Fournier, E., Tharreau, D., and Gladieux, P. 2020. Ecological differentiation and incipient speciation in the fungal pathogen causing rice blast. bioRxiv 2020.06.02.129296.

Valent, B., Crawford, M. S., Weaver, C. G., and Chumley, F. G. 1986. Genetic studies of fertility and pathogenicity in Magnaporthe grisea (Pyricularia oryzae). Iowa State J. Res. 60:569-594.

Wang, M., Yu, Y., Haberer, G., Marri, P. R., Fan, C., Goicoechea, J. L., Zuccolo, A., Song, X., Kudrna, D., Ammiraju, J. S. S., Cossu, R. M., Maldonado, C., Chen, J., Lee, S., Sisneros, N., de Baynast, K., Golser, W., Wissotski, M., Kim, W., Sanchez, P., Ndjiondjop, M. N., Sanni, K., Long, M., Carney, J., Panaud, O., Wicker, T., Machado, C. A., Chen, M., Mayer, K. F., Rounsley, S., and Wing, R. A. 2014. The genome sequence of African rice (Oryza glaberrima) and evidence for independent domestication. Nat. Genet. 46:982-988. 
Wang, X., Jia, Y., Wamishe, Y., Jia, M. H., and Valent, B. 2017. Dynamic changes in the rice blast population in the United States over six decades. Mol. Plant-Microbe Interact. 30:803-812.

Weir, B. S., and Cockerham, C. C. 1984. Estimating F-statistics for the analysis of population structure. Evolution 38:1358-1370.

Xia, J. Q., Correll, J., Lee, F. N., and Ross, W. J. 2000. Regional population diversity of Pyricularia grisea in Arkansas and the influence of host selection. Plant Dis. 84:877-884.

Xia, J. Q., Correll, J. C., Lee, F. N., Marchetti, M. A., and Rhoads, D. D. 1993. DNA fingerprinting to examine microgeographic variation in the Magnaporthe grisea (Pyricularia grisea) population in two rice fields in Arkansas. Phytopathology 83:1029-1035.
Xu, J. R., and Hamer, J. E. 1995. Assessment of Magnaporthe grisea mating type by spore PCR. Fungal Genet. Newsl. 42:80-81.

Zeigler, R. S. 1998. Recombination in Magnaporthe grisea. Annu. Rev. Phytopathol. 36:249-275.

Zeigler, R. S., Cuoc, L. X., Scott, R. P., Bernardo, M. A., Chen, D. H., Valent, B., and Nelson, R. J. 1995. The relationship between lineage and virulence in Pyricularia grisea in the Philippines. Phytopathology 85: 443-451.

Zhong, Z., Chen, M., Lin, L., Han, Y., Bao, J., Tang, W., Lin, L., Lin, Y., Somai, R., Lu, L., et al. 2018. Population genomic analysis of the rice blast fungus reveals specific events associated with expansion of three main clades. ISME J. 12:1867-1878. 